\title{
Kontribusi Pendidikan Kristen Bagi Pembentukan Rohani Dan Perilaku Anak Usia Dini
}

\author{
Desetina Harefa, ${ }^{* 1}$ Otieli Harefa, ${ }^{2}$ Linda Dewi Terserani Lase ${ }^{3}$ \\ Prodi Prodi PK AUD, STT Real Batam \\ Prodi PAK, STT Real Batam \\ Prodi PK AUD, STT Real Batam \\ desetina.harefa@gmail.com
}

\begin{abstract}
The writing of this article departs from problems that are often seen in the community around us today, where early childhood, especially those who have been in kindergarten, many have been neglected by Christian educators, so that children's spirituality has not formed since small. Or often we see how Christian teachers do not really do their job, arguing that early childhood still does not know and understand anything. In connection with that, in the discussion of writing this article the authors formulated the problem, namely first how the Kindergarten School as a firstlevel formal educational institution pays attention to the learning of Christian education as the basis for spiritual formation and early childhood behavior. Second, what and how Christian Education and educators contribute to the spiritual formation and behavior of early childhood. After everything is analyzed, the author can finally conclude that Christian religious education in schools has a major contribution to the efforts of spiritual formation and early childhood behavior.Keywords:Christian Education, Early Childhood and Spiritual Formation
\end{abstract}

\begin{abstract}
Abstrak
Penulisan artikel ini berangkat dari masalah-masalah yang sering terlihat dalam masyarakat sekitar kita saat ini, dimana anak-anak usia dini khususnya mereka yang telah duduk di bangku Sekolah Taman Kanak-kanak, banyak terabaikan oleh para pendidik Kristen, sehingga kerohanian anak belum terbentuk sejak kecil. Atau sering kita melihat bagaimana guru-guru agama Kristen tidak dengan sungguh-sungguh melakukan tugasnya, dengan alasan bahwa anak usia dini masih belum tahu dan mengerti apa-apa. Sehubungan dengan itu maka dalam pembahasan penulisan artikel ini penulis merumuskan permasalahannya yaitu pertama bagaimana Sekolah Taman Kanak-kanak sebagai lembaga pendidikan formal tingkat pertama memberi perhatian terhadap pembelajaran pendidikan Kristen sebagai dasar pembentuk rohani dan prilaku anak usia dini. Kedua, apa dan bagaimana kontribusi Pendidikan dan para pendidik Kristen terhadap pembentukan rohani dan prilaku anak usia dini. Setelah semuanya di analisa maka akhirnya bisa penulis simpulkan bahwa pendidikan agama Kristen di sekolah mempunyai kontribusi yang besar bagi usaha pembentukan rohani dan prilaku anak usia dini.

Kata kunci: Pendidikan Kristen, Anak Usia Dini dan Pembentukan Rohani
\end{abstract}

\section{PENDAHULUAN}

Berbicara tentang peran Pendidikan Agama Kristen pada pembentukan rohani anak usia dini berarti tidak bisa lepas dari konsepsi Alkitab yang mencatat tentang penugasan kepada orang tua sebagai pendidik untuk mengajarkan Firman Tuhan kepada anak-anaknya sebagai mana tertulis dalam kitab Ulangan 6:6-7. Ayat ini memperlihatkan dengan jelas 
bahwa anak-anak harus diajar dengan pendidikan agama supaya mereka sejak usia dini terbentuk dalam mengasihi Allah dengan benar. Bahkan dengan membaca ayat ini dapat dimengerti bahwa betapa Allah sangat memberikan perhatian dan bimbingan kepada anakanak sebagai generasi penerus. Anak-anak tidak bisa secara otomatis mengerti tentang Allah dengan segala kebenaran yang ada di dalamnya, tetapi mereka harus diajar dalam berbagai pokok iman Kristen, sampai mereka percaya dan terbentuk kepercayaanya. Hal ini sejalan dengan tujuan dari Pendidikan Agama Kristen untuk mengajak, membantu, menghantar seseorang untuk mengenal kasih Allah yang nyata dalam Yesus Kristus, sehingga dengan pimpinan Roh Kudus ia datang ke dalam persekutuan yang hidup dengan Tuhan. Hal tersebut dinyatakan dalam kasihnya terhadap Allah dan sesama, yang dihayati dalam hidupnya sehari-hari, baik dengan kata-kata maupun perbuatan selaku anggota tubuh Kristus. ${ }^{1}$ Allah merindukan seluruh umatnya baik yang dewasa maupun anak-anak dapat mengenal dan mengasihi Dia dengan segenap hati dan kekuatan mereka. Dengan demikian sudah sepatutnya seluruh para pengajar kristen baik di lingkungan sekolah, gereja dan keluarga harus memahami secara benar Firman Allah supaya memberikan pendidikan, pembinaan dan perhatian serta pelayanan kepada anak-anak sejak usia dini. Pendidik kristen sepatutnya membuat keputusan tentang praktek pendidikan anak usia dini dalam keseharian di kelas berdasarkan pengetahuan tentang pertumbuhan jasmani dan rohani. Iris V. Cully berkata : "Para pendidik Kristen mesti menyadari betapa pentingnya anak-anak harus berakar dalam iman dan kehidupan mereka harus dibimbing oleh pekerjaan Roh Kudus. Itulah sebabnya para pendidik harus memiliki pemahaman teologi dan penelitian Alkitab yang baik, khususnya pengertian tentang pendidikan Kristen"2 ${ }^{2}$. Para pendidik Kristen khususnya bagi mereka yang menjadi guru Pendidikan Agama Kristen di Sekolah Taman Kanak-kanak atau PAUD, mereka mempunyai tanggungjawab yang besar dalam mengajarkan pendidikan Kristen yang berdampak bagi pembentukan rohani anak sehingga mereka bertumbuh dalam iman. Pendidikan Agama Kristen untuk anak digambarkan sebagai sebuah proses yang menolong dan membimbing setiap anak untuk menempuh setiap level perkembangannya sampai pada kepenuhannya, dan juga dalam menghadapi soal hidupnya dalam sebuah konteks konsep Kristen. ${ }^{3}$ Pemahaman ini mengungkapkan bahwa betapa pentingnya peran dan kontribusi para pendidik Kristen di sekolah dalam membentuk kerohanian dan prilaku anak.

\section{METODE}

Metode penulis Artikel ini adalah Metode analisa deskriptif interpretatif dengan cara menganalisa, menyusun dan mengklarifikasikan data untuk diinterpretasikan dimasa kini. ${ }^{4}$ Data-data yang diperoleh dan dibutuhkan dalam pembahasan, penulis melakukan

\footnotetext{
${ }^{1}$ Daniel Nuhamara, "Pembimbing PAK," Jurnal Info Media (2009). 31

${ }^{2}$ Iris V Cully, Dinamika Pendidikan Kristen (Jakarta: BPK Gunung Mulia, 2011). hal. xi

${ }^{3}$ Carrie Lou Goddard, The Christian Education of Children (New York: Abingdon Press, 1996). Hal.175

${ }^{4}$ Lexy J Moleong, Metodologi Penelitian Kualitatif (Bandung: Remaja Rosdakarya, 2006). Hal. 5
} 
studi kepustakaan dengan menggunakan buku-buku berkaitan dengan Pendidikan Kristen untuk membentuk rohani dan perilaku anak usia dini.

\section{HASIL DAN PEMBAHASAN}

\section{Perintah Tuhan dalam Amanat Agung}

Pendidikan Agama Kristen merupakan perintah dari Tuhan Yesus Kristus yang disebut dalam Amanat Agung (Mat. 28:18-20). Yesus sebagai guru agung melaksanakan Pendidikan Kristen diseluruh aspek pelayanannya diberbagai tempat, dimana para pendengarnya melingkupi seluruh golongan umur. Pendidikan Agama Kristen berusaha membimbing setiap pribadi kesemua tingkat pertumbuhan kearah pengenalan dan pengalaman tentang rancana Allah ke setiap aspek kehidupan. Pendidikan Kristen akan membimbing orang mengenal Allah yang maha kudus adil, dan benar. Ia menghendaki kehidupan yang berdisiplin dalam segala segi menyangkut segi fisik, mental, moral, politik dan lain-lainnya bagi keluarga Kristen"5. Maka dari itu setiap orang Kristen termasuk anak-anak usia dini perlu diberikan pendidikan Kristen dalam segala segi kehidupannya agar menjadi orang Kristen yang dewasa dan yang hidup sesuai dengan kehendak Tuhan. Berbicara mengenai kehidupan sesuai dengan kehendak Tuhan bukan dalam arti secara langsung sama seperti Allah tetapi tahap demi tahap belajar untuk hidup sesuai dengan kebenaran Firman Tuhan dan sesuai dengan apa yang dikehendaki oleh Allah.

Fokus penyelenggaraan pendidikan pada anak usia dini yaitu meletakan dasar ke arah pertumbuhan dan perkembangan fisik yang berupa koordinasi motorik halus dan kasar, kecerdasan yang mampu membuat daya pikir, daya cipta, kecerdasan emosi, serta kecerdasan spiritual, sosio emosional yang menyangkut sikap dan perilaku serta agama, bahasa dan komunikasi sesuai dengan keunikan dan tahap-tahap perkembangan yang dilalui oleh anak usia dini. Menurut UU Sisdiknas No.20/2003, pasal 28 ayat 1bahwa rentang waktu bagi anak usia dini adalah 0-6 tahun. Mendidik anak di usia dini bukan lagi sekedar penting, tetapi para ahli psikologi berkata itu adalah proses maha penting. Doronthy Rich mengungkapkan "anak-anak dilahirkan untuk belajar, mereka adalah makhluk alami yang penuh dengan rasa ingin tahu dan memiliki hasrat yang tinggi untuk tahu, otak mereka sedang dalam masa pemenuhan, sehingga usia anak 1-6 tahun disebut sebagai usia emas dalam mendidik dan membentuk anak"6. Kebenaran ini juga dipaparkan oleh Timothy Wibowo dalam tulisan artikelnya yang berkata bahwa "Pada usia dini 0-6 tahun, otak berkembang sangat cepat perkembangannya hingga 80 persen. Pada usia tersebut otak anak mampu menerima dan menyerap berbagai macam informasi yang baik dan buruk. Dimasa-masa ini anak mengalami perkembangan fisik, mental maupun spiritual akan mulai terbentuk. Dengan demikian jelas bahwa usia dini adalah waktu yang tepat

\footnotetext{
${ }^{5}$ B. Samuel Sidjabat, Strategi Pendidikan Kristen, ed. editor.pbmr@penerbitandi.com (Yogyakarta: Penerbit ANDI, 1996). 35

${ }^{6}$ Dorothy Rich Ed.D, Metode Megaskills Untuk Usia 1-6 Tahun (Jakarta: PT. Miza Publika, 2010). 13
} 
memperkenalkan pendidikan Kristen bagi anak, bila tidak maka waktu emas ini akan berlalu sia-sia. Sehubungan dengan keberhasilan mendidik anak di usia dini, Doni Kusuma mengungkapkan bahwa "Pendidikan anak usia dini hendaknya diberikan secara terorganisir dan seimbang baik antara pendidikan dan pembentukan secara pengetahuan, skill dan kerohanian. Hal ini harus dilakukan secara terus menerus sampai anak mengetahuinya bahkan mampu mempraktekannya dalam kehidup sehari-hari" ${ }^{7}$. Artinya pendidikan anak usia dini harus diberikan secara seimbang, antara pendidikan umum dan pendididkan rohani sebagai dasar pembentukan. tidak hanya fokus kepada pengetahuan atau skill semata, yang lebih banyak diutamakan kebanyakan guru modern.

Pembentukan rohani tidak bisa dipisahkan dengan pendidikan Kristen, sebab ajaran atau pendidikanlah yang mampu membentuk manusia dalam kerohanian dari waktu ke waktu. Iris V. Cully berkata bahwa kegiatan dari pendidikan Kristen adalah membentuk anak-anak Tuhan dalam segala karakter Allah. Pendidikan Kristen berperan untuk menghubungkan manusia dengan AllahNya, sehingga sedapat mungkin manusia bisa hidup sesuai dengan karakter AllahNya ${ }^{8}$. Pribadi yang dibentuk dalam konteks ini adalah termasuk anak usia dini, dimana yang bisa membentuk anak dalam kerohanian dan prilaku yang baik adalah hanya lewat pendidikan Kristen yang berpusatkan Alkitab, baik yang dilakukan di rumah tangga, gereja maupun sekolah. Anak-anak tidak bisa dibentuk hanya dengan teguran dan disiplin yang kuat, tetapi harus dilandasi oleh pendidikan Kristen yang baik, anak terbentuk dalam kerohanian, sehingga ia berprilaku baik sesuai dengan nilainilai dari pendidikan Kristen itu sendiri. Kristianto mengungkapkan bahwa anak di usia 2-3 tahun mempunyai iman yang sederhana, yang kadang digambarkan dalam bentuk yang ia mengerti, mereka bisa diajar berdoa dengan melipat tangan, menundukan kepala atau bernyanyi lagu rohani ${ }^{9}$. Lebih lanjut dikatakan bahwa Di usia ini mereka bisa mengamalkan imannya secara sederhana seperti lewat doa yang pendek, nyanyian rohani, halafal Firman Tuhan ${ }^{10}$. Judith Allen mengungkapkan bahwa anak usia 4-6 tahun, sangat memungkinkan mereka bertumbuh dan berkembang secara rohani, sebab mereka telah bertumbuh secara kognitif sekalipun hal itu disesuaikan dengan propodional pertumbuhan mereka secara fisik. ${ }^{11}$

Bila melihat dari penjelasan di atas maka pendidikan PAK bagi anak sejak usia dini sangat penting. Oleh karena itu Pendidikan Kristen harus mampu untuk memperkenalkan Allah kepada anak-anak lewat pembelajaran media yang sesuai. Guru Kristen bukan hanya berkewajiban menyampaikan materi ajar kepada anak, tetapi bertanggungjawab memperkenalkan Allah kepada anak karena anak perlu mengenal Tuhan

${ }^{7}$ Doni Koesoema A, Pendidikan Karakter-Strategi Mendidik Anak Di Zaman Global (Jakarta: PT. Grasindo, 2007). 60

${ }^{8}$ Cully, Dinamika Pendidikan Kristen. 73

${ }^{9}$ Singgih D.dan Ny Y Gunarsa, Psikologi Untuk Membimbing (Jakarta: BPK Gunung Mulia, 1981). 36

${ }^{10}$ Ibid. 90

${ }^{11}$ Judit Allen Shelly, Kebutuhan Rohani Anak (Bandung: Kalam Hidup, 2003).22 
secara pribadi ${ }^{12}$ Mungkin ada yang berasumsi apakan anak di tingkat usia dini mampu memahami hal-hal tentang Allah? jawabanya tentu tidak sepaham dengan orang dewasa, akan tetapi anak usia dini tidak berarti tidak bias mengerti tentang Allah. Anak usia dini menurut perkembangannya masih belum bisa berfikir hal-hal yang abstrak, namun ia mampu memahami Allah ketika diajarkan dalam bentuk yang sederhana seperti Tuhan itu baik, ia menolong tepat pada waktunya seperti orang tua yang dapat menolong anaknya tepat waktunya, dimana hal ini harus diajarkan secara berulang-ulang sampi tertanam dalam hatinya bahwa Allah itu baik. Tuntutan yang paling penting adalah bagaimana agar pengulangan itu bisa menjadi pokok perhatian seluruh orang yang bertanggung jawab terhadap pendidikan anak. Pengajaran Pendidikan Agama Kristen kepada anak usia dini diharapkan berulang-ulang dan bukan hanya berhenti di ranah teori, tetapi membiarkan roh anak mengalami sentuhan dari kuasa Roh Kudus, sehingga membawa sebuah perubahan. Pengajaran harus mengisi iman Kristen kedalam diri anak sehingga dia memahami dan mengikutinya sebagai karakter dan model tingkah lakunya.

Kedua, pendidikan kristen harus mampu mendekatkan anak kepada Tuhan. Dalam salah satu nats (Markus 10:13-16) diceritakan tentang bagaimana Yesus sedemikian akrabnya dengan anak-anak. Kehidupan anak-anak digambarkan dengan sesuatu yang indah, yang menyenangkan dan penuh kebahagiaan. Lebih dari itu Yesus menghayati kebersamaanNya dengan anak-anak sebagai suatu simbol pertemuan dengan Allah sendiri, suatu bentuk penghadiran Kerajaan Allah sendiri. Yesus marah kepada murid-muridnya yang ternyata menghalangi kehadiran anak-anak kepada Yesus. Dia mengatakan, jangan cegah mereka datang kepadaKu, sebab merekalah yang memiliki kerajaan sorga. Muridmurid sama dengan orang-orang dewasa atau bahkan sama dengan orang tua, yang senantiasa menganggap anak-anak tidak perlu mengetahui Firman Tuhan. Tidak atau belum saatnya untuk membinanya. Bahkan urusan mereka adalah prioritas yang terakrir dari seluruh urusan. Sikap seperti itu sebenarnya justru membatasi dan mengucilkan mereka dari kedekatan dengan Tuhan.

Ketiga Pendidikan Kristen berkontribusi untuk membangun karakter dan tingkah laku anak. Pembentukan budi pekerti dan inteligensi anak dirasakan sudah sangat mendesak dan tidak bisa dituna-tunda. Pembangunan dan pembinaan akhlak dan moral manusia memang harus dimulai semenjak usia dini. Pembinaan untuk anak tidak hanya penting bagi kesuksesan hidup tetapi sangat penting untuk pembangunan masyarakat dan peradaban manusia yang luhur ${ }^{13}$.

Keempat pendidikan Kristen berkontribusi untuk membangun kerohanian anak. Judith Allen berkata bahwa anak-anak usia dini mempunyai kehausan akan Allah lewat keingin tahuannya, oleh sebab itu para pendidik Kristen seperti guru dan orang tua harus

\footnotetext{
${ }^{12}$ Andrew. D Laster, Pelayanan Pastoral Bersama Anak-Anak Dalam Krisis (Malang: Seminari Alkitab Asia Tenggara, 2003). 39

${ }^{13}$ Tati Prihati, Penerapan Moral Bagi Anak Usia Dini (Jakarta: Bina Media Informasi, 2009). 7
} 
mampu memenuhinya lewat proses pembelajaran tentang nilai-nilai dan kebenaran Kristen $^{14}$. Untuk mencapai iman yang demikian. banyak usaha yang ditempuh setiap orang untuk membentuk dan membangun imannya. Untuk itu setiap guru wajib mengajarkan teori tentang nilai-nilai yang harus diterapkan kepada siswa untuk memiliki kepribadian yang beriman kepada Yesus. Kemudian, guru juga berperan memberi contoh dan teladan dalam menerapkan nilai-nilai yang diajarkannya tersebut dengan demikian, siswa dapat meneladaninya.

Kelima, Pendidikan Kristen berkontribusi untuk membentuk nilai-nilai Kristiani bagi anak. Indra Sanjaya berkata, bahwa anak diusia dini dengan nuraninya yang sangat kuat, ingin terus mengetahui sesuatu dimana hal ini diwujudkan dalam berbagai bentuk pertanyaan dengan hal apa saja yang dilihatnya, termasuk hal-hal tentang Allah, guru dalam kesempatan ini bisa membangun kebiasaan-kebiasaan rohani yang baik bagi anak,seperti berdoa, mengasihi, mengampuni, dan lain sebagainya ${ }^{15}$. Artinya dengan rasa keingin tahuannya yang didrong oleh hati nuraninya, memudahkan bagi guru untuk mengajarkan hal-hal yang baik bagi anak usia dini, sehingga hal itu pada akhirnya menjadi karakter rohani mereka. Lebih jauh Indra berkata bahwa "anak usia dini sangat membutuhkan pendampingan untuk membimbing mereka dalam iman, mereka masih polos dan tulus, guru harus mengisinya dengan kebenaran Alkitab yang diajarkan dalam bentuk sederhana ${ }^{16}$." Ketika anak diajarkan kebiasaan untuk menyebutkan Firman Tuhan, berdoa sebelum belajar, sebelum, ini merupakan cara yang baik untuk dibiasakan kepada anak usia dini, sehingga mereka terbentuk dalam hal-hal yang rohani. Ketika mereka diajarkan dengan metode pembiasaan hal-hal yang baik secara sederhana seperti santun dalam berbicara kepada guru, menghormati milik temannya, berbagi dengan temannya dan nilainilai Kristen lainnya, maka mereka akan bertumbuh dalam kebiasaan itu. Pengembangan dan pembentukan kebiasaan-kebiasaan yang sebut sebagai nilai-nilai iman Kristen tentu bukan hal yang mudah, tetapi harus dilakukan dalam ketekunan dan kesetiaan, dimana para pendidik Kristen dalam konteks ini dibutuhkan komitmen untuk terus melakukannya, sampai anak usia dini terbentuk di dalamnya. Pengembangan nilai-nilai ini juga tidak bisa hanya menjadi tanggungjawab guru Kristen di sekolah formal semata, tetapi harus dilakukan secara bersama-sama dengan para pendidik lainnya baik di gereja terlebih di rumah tangga.

Keenam Pendidikan Kristen berkontribusi untuk mentransformasi kehidupan anak. Tujuan akhir yang ingin dicapai dalam satu proses pembelajaran adalah Perubahan yang terjadi dalam konsep berpikir, pola berpikir, gaya berpikir dan hasil berpikir yang pada umumnya diwujudkan dalam tindakan dan perbuatan. Proses pembelajaran PAK di sekolah termasuk kepada anak usia dini, supaya anak-anak peserta didik mengalami

\footnotetext{
${ }^{14}$ Shelly, Kebutuhan Rohani Anak. 12

${ }^{15}$ V. Indra Sanjaya, Dongeng Mendekatkan Kitab Suci Kepada Anak (Jakarta: Kanisius, 2009). 44

${ }^{16}$ Ibid. 45
} 
perubahan hidup dari yang tidak baik menjadi baik atau supaya terbiasa dalam segala halhal yang baik. J. Thompson berkata "tentu anak-anak tidak hanya dibentuk oleh satu aspek setelah ia lahir, tetapi lingkungan dekat dan jauh dengan segala keberadaanya turut membentuk anak-anak dalam pertumbuhannya, oleh sebab itu tugas dari para pendidik Kristen baik disekolah, gereja dan terlebih di rumah tangga adalah membimbing anak mencapai satu perubahan sikap dan perbuatan ${ }^{17}$. Artinya selama dua puluh empat jam dalam sehari, kehidupan anak tidak hanya dilingkupi oleh nuansa rohani, tetapi aspekaspek yang lain seperti budaya dan kebiasaan dalam keluarga dan lingkungan turut membentuk anak.

\section{KESIMPULAN}

Jadi dapat disimpulkan, pertama, Pendidikan Kristen pada Anak Usia Dini mempunyai peranan yang sangat penting, khususnya dalam membina dan membentuk kerohanian anak sejak dari kecil. Pembelajaran ini, tidak bisa digantikan oleh pembelajaran budi pekerti lainnya, sebab pendidikan Kristen berbicara tentang hal-hal rohani.

Kedua, Pendidikan Kristen bagi anak usia dini harus dilakukan dengan strategi tertentu, sesuai dengan perkembangan anak fisik dan psikologi anak. Pembiasaanpembiasaan yang baik adalah salah satu metode terbaik untuk mendidik dan membentuk rohani anak usia dini.

Ketiga, tugas mendidik dan membentuk kerohanian anak usia dini adalah perintah mulia dari pada Tuhan Yesus. Ia mau supaya anak-anak dibawa kepadanya lewat pembelajaran PAK, karena anak anak membutuhkan keselamatan dari Tuhan, oleh sebab itu guru PAK memegang peranan penting untuk mewujudkan harapan pembentukan rohani dan prilaku bagi anak usia dini yang diharapkan oleh Tuhan dan tentunya orang tua. Seorang gur PAK harus mempunyai komptensi rohani yang cukup untuk membawa anakanak kepada Tuhan.

Keempat, Kontribusi terbesar pendidikan Kristen bagi anak usia dinia adalah pengenalan akan Allah dan karyanya kepada orang percaya termasuk anak-anak di usia dini, serta membentuk nilai-nilai iman kristiani dalam kehidupan anak usia dini.

Kelima, Anak usia dini merupakan objek dari pembelajaran PAK, sebab Pendidikan Kristen bukan saja mebentuk mereka secara rohani, tetapi juga mentransformasi kehidupan setiap anak, sehingga mereka mengalami perubahan baik dalam sikap maupun dalam tindakan.

\footnotetext{
${ }^{17}$ Marjorie J. Thompson, Keluarga Sebagai Pusat Pembentukan Rohani Anak (Jakarta: BPK Gunung Mulia, 2001). 45
} 


\section{KEPUSTAKAAN}

A, Doni Koesoema. Pendidikan Karakter-Strategi Mendidik Anak Di Zaman Global. Jakarta: PT. Grasindo, 2007.

Cully, Iris V. Dinamika Pendidikan Kristen. Jakarta: BPK Gunung Mulia, 2011.

Ed.D, Dorothy Rich. Metode Megaskills Untuk Usia 1-6 Tahun. Jakarta: PT. Miza Publika, 2010.

Goddard, Carrie Lou. The Christian Education of Children. New York: Abingdon Press, 1996.

Gunarsa, Singgih D.dan Ny Y. Psikologi Untuk Membimbing. Jakarta: BPK Gunung Mulia, 1981.

Laster, Andrew. D. Pelayanan Pastoral Bersama Anak-Anak Dalam Krisis. Malang: Seminari Alkitab Asia Tenggara, 2003.

Moleong, Lexy J. Metodologi Penelitian Kualitatif. Bandung: Remaja Rosdakarya, 2006.

Nuhamara, Daniel. "Pembimbing PAK." Jurnal Info Media (2009).

Prihati, Tati. Penerapan Moral Bagi Anak Usia Dini. Jakarta: Bina Media Informasi, 2009. Sanjaya, V. Indra. Dongeng Mendekatkan Kitab Suci Kepada Anak. Jakarta: Kanisius, 2009.

Shelly, Judit Allen. Kebutuhan Rohani Anak. Bandung: Kalam Hidup, 2003.

Sidjabat, B. Samuel. Strategi Pendidikan Kristen. Edited by editor.pbmr@penerbitandi.com. Yogyakarta: Penerbit ANDI, 1996.

Thompson, Marjorie J. Keluarga Sebagai Pusat Pembentukan Rohani Anak. Jakarta: BPK Gunung Mulia, 2001. 